\title{
The Crystal Structure of Boleite-A Mineral Containing Silver Atom Clusters
}

\author{
ROLAND C. ROUSE \\ Department of Geology and Mineralogy, ${ }^{*}$ The University of Michigan, Ann Arbor, Michigan \\ 48104
}

Received March 10, 1972

\begin{abstract}
The mineral boleite, $\mathrm{Pb}_{26} \mathrm{Ag}_{9} \mathrm{Cu}_{24} \mathrm{Cl}_{62}(\mathrm{OH})_{48}$, is cubic, space group $P m 3 m$, with $a=15.29 \AA$. Lead and silver atoms form a distorted body-centered array leading to octahedral groupings of these atoms. The silver atoms and their coordinating chlorines form $\mathrm{Ag}_{6} \mathrm{Cl}_{8} \mathrm{Cl}_{6}$ groups similar to those in the metal cluster compounds $\mathrm{MoCl}_{2}$ and $\mathrm{WCl}_{2}$. Lead and copper atoms are in distorted square antiprismatic and tetragonal bipyramidal coordination, respectively.
\end{abstract}

\section{Introduction}

Boleite is a lead copper oxychloride mineral which occurs as deep blue crystals of cubic form. These cubes are zoned and consist of an optically isotropic or quasi-isotropic core and a birefringent outer rim of complex structure. The cube faces are sometimes occupied by epitaxial overgrowths of the related species pseudoboleite and cumengite. Boleite has been studied in detail by Mallard and Cumenge ( $I$ ), Friedel (2), and Hocart (3). They all considered the birefringent material to be tetragonal and untwinned and the isotropic core to be pseudocubic due to twinning. Hadding (4) and Gossner (5), however, concluded that boleite was truly cubic. Ito (6) proposed a tetragonal structure based upon twinning of cubic units at the unit cell level. The tetragonal twinned cell has a "twinned space group" $I 4 / \mathrm{mmm}$ and parameters $a=15.27$ and $c=60.94 \AA$. It consists of four cubic cells stacked along [001] and related by mirror planes at $z=\frac{1}{4}$ and $\frac{3}{4}$ and by a glide plane at $z=\frac{1}{2}$.

In a restudy of the boleite group Winchell (7) concluded that the outer rim of boleite is either an intergrowth of two species (perhaps boleite and pseudoboleite) or consists of boleite lamellae having different orientations. He also performed heating stage experiments on boleite between 25 and $265^{\circ} \mathrm{C}$ where crystal decomposition began. Between 80 and $180^{\circ} \mathrm{C}$ the color changed

* Contribution No. 306, The Mineralogical Laboratory. gradually from blue to green, while the birefringent rim and the quasi-isotropic core merged into an apparently homogeneous, isotropic phase. Upon cooling, the blue color returned but the isotropy persisted. From these and other observations Winchell proposed that boleite undergoes an inversion from a pseudocubic form to a cubic one with increasing temperature.

\section{Symmetry and Composition}

To determine the true symmetry of boleite, isotropic cleavage fragments were examined by the author using the Weissenberg and precession methods and $\mathrm{Cu} K \alpha$ and $\mathrm{MoK} \alpha$ radiation. As reported by (4) and (5), isotropic boleite is cubic, space group $P m 3 m$, with no evidence of twinning. The unit cell parameter, as determined from Bradley-Jay extrapolations of single-crystal diffractometer data, is $a=15.29 \AA$. Unit cell contents calculated from the chemical analysis of isotropic boleite reported in (2) are

$$
\mathrm{Pb}_{25.88} \mathrm{Ag}_{9.16} \mathrm{Cu}_{23.54} \mathrm{Cl}_{61.58} \mathrm{O}_{49.87} \mathrm{H}_{52.65} \text {. }
$$

A qualitative chemical analysis with the electron microprobe showed $\mathrm{Pb}, \mathrm{Ag}, \mathrm{Cu}$, and $\mathrm{Cl}$ as the only elements present. Oxygen was not determined due to instrumental limitations. The above results accord well with the formula $\mathrm{Pb}_{26} \mathrm{Ag}_{9}$ $\mathrm{Cu}_{24} \mathrm{Cl}_{62}(\mathrm{OH})_{48}$ determined by crystal structure analysis. The observed and calculated densities are 5.054 and $5.062 \mathrm{~g} / \mathrm{cm}^{3}$, respectively. 
TABLE I

Observed and Calculated Structure Factors ${ }^{a}$

\begin{tabular}{|c|c|c|c|c|c|c|c|c|c|c|c|c|c|c|}
\hline$h$ & $F_{\text {obsd }}$ & $F_{\text {cald }}$ & $h$ & $F_{\text {obsd }}$ & $F_{\text {cald }}$ & $h$ & $F_{\text {obsd }}$ & $F_{\text {cald }}$ & $h$ & $F_{\text {obsd }}$ & $F_{\text {cald }}$ & $h$ & $F_{\text {obsd }}$ & $F_{\text {cald }}$ \\
\hline$(0,0)$ & & & $(4,0)$ & & & $(1,1)$ & & & $(5,1)$ & & & \multicolumn{3}{|c|}{$(3,2)-($ continued $)$} \\
\hline 3 & 748 & 683 & 4 & 2388 & 2392 & 2 & 161 & 90 & 5 & 855 & 655 & 7 & 111 & 89 \\
\hline 4 & 2295 & 2413 & 5 & 1001 & 929 & 3 & $35 t$ & 24 & 6 & 28 & 2 & 8 & & 471 \\
\hline 5 & 1762 & 1707 & 6 & 1082 & 947 & 4 & 280 & 23 & 7 & 100 & 21 & 9 & 97 & 15 \\
\hline 6 & 1606 & 1639 & 7 & 102 & 29 & 5 & 11 & 42 & 8 & 540 & 538 & 10 & 370 & 457 \\
\hline 7 & 837 & 10 & 8 & 730 & 724 & 6 & 567 & 474 & 9 & 598 & 596 & 11 & 9 & 423 \\
\hline 8 & 1935 & 2046 & 9 & 109 & 188 & 7 & 33 & 27 & 10 & 82 & 34 & 12 & 26 & 566 \\
\hline 9 & 287 & 333 & 10 & 931 & 964 & 8 & 2 & 25 & 11 & 281 & 294 & 13 & 314 & 370 \\
\hline 10 & 1967 & 2062 & 11 & 217 & 152 & 9 & 805 & 794 & 12 & 72 & 54 & $(4,2)$ & & \\
\hline 11 & 211 & 251 & 12 & 1143 & 1185 & 10 & 70 & 49 & 13 & 946 & 1023 & , & & \\
\hline 12 & 975 & 1078 & 13 & 119 & 76 & 11 & 552 & 536 & & & & 4 & 1144 & 1010 \\
\hline 13 & 192 & 200 & & & & 12 & 21 & 157 & $(6,1)$ & & & 5 & 219 & 202 \\
\hline & & & $(5,0)$ & & & 13 & 383 & 424 & 6 & 714 & 623 & 6 & $5 t$ & 471 \\
\hline$(1,0)$ & & & 5 & 773 & 732 & & & & 7 & 432 & 365 & 7 & 2 & 226 \\
\hline 2 & 178 & 207 & 6 & 187 & 43 & $(2,1)$ & & & 9 & 94 & 70 & 8 & 52 & 469 \\
\hline 3 & 444 & 406 & 7 & 642 & 597 & 2 & 648 & 604 & 10 & 291 & 223 & 9 & 63 & 554 \\
\hline 4 & 11 & 2 & 8 & 11 & 61 & 3 & 28 & 23 & 11 & 241 & & 10 & 64 & 694 \\
\hline 5 & 104 & 5 & 9 & 23 & 21 & 4 & 45 & 3 & 12 & 159 & 132 & 11 & 86 & 116 \\
\hline 6 & 11 & 5 & 10 & 60 & 6. & 5 & 36 & 26 & & & & 12 & 80 & 87 \\
\hline 7 & 80 & 1 & 1 & 25 & 25 & 6 & 99 & 8 & $(7,1)$ & & & 13 & 324 & 336 \\
\hline 8 & 314 & 323 & 12 & 81 & 12 & 7 & 56 & 50 & 7 & 983 & 916 & $(5,2)$ & & \\
\hline 9 & 4. & 402 & 13 & 529 & 586 & 8 & 20 & 18 & 8 & 2 & 2 & 5 & 1067 & 981 \\
\hline 10 & 452 & 441 & & & & 9 & 167 & 13 & 9 & 1 & 1 & 6 & 298 & 282 \\
\hline 11 & 234 & 228 & $(6,0)$ & & & 10 & 459 & 42 & 10 & & & 7 & 707 & 661 \\
\hline 12 & 32 & 320 & 6 & 1604 & 1616 & 11 & 79 & 5 & 11 & 6 & 64 & 8 & & 315 \\
\hline 13 & 349 & 381 & 7 & 607 & 5 & 12 & 75 & 1 & 12 & 419 & 4 & 9 & & 404 \\
\hline & & & 8 & 105 & 111 & 13 & 171 & 207 & & & & 10 & 3 & 348 \\
\hline$(2,0)$ & & & 9 & 107 & 103 & 14 & 237 & 211 & $(8,1)$ & & & 11 & 9 & 30 \\
\hline 3 & 570 & 430 & 10 & 838 & 810 & & & & 8 & 112 & 78 & 12 & 79 & 24 \\
\hline 4 & 405 & 409 & 11 & 27 & 285 & 1) & & & & & & $(6,2)$ & & \\
\hline 5 & 1044 & 954 & 12 & 80 & 3 & 3 & 998 & 934 & $(9,1)$ & & & 6 & 16 & 1491 \\
\hline 6 & 114 & 26 & 13 & 248 & 263 & 4 & 4 & 403 & 0 & 876 & & 7 & 398 & $\begin{array}{r}1491 \\
348\end{array}$ \\
\hline 7 & 91 & 81 & & & & 5 & 9 & 776 & 10 & 180 & 184 & 8 & 125 & 148 \\
\hline 8 & 959 & 938 & $(7,0)$ & & & 6 & 107 & $n$ & & & & 9 & 328 & 266 \\
\hline 9 & 10 & 6 & 7 & 666 & 595 & 7 & 110 & 969 & $(2,2)$ & & & 10 & 859 & 890 \\
\hline $\begin{array}{l}10 \\
11\end{array}$ & $\begin{array}{l}71 \\
15\end{array}$ & & 8 & 33 & 30 & 9 & 9 & 58 & 3 & & & 11 & 636 & 704 \\
\hline $\begin{array}{l}1 \\
1\end{array}$ & $\begin{array}{l}15 \\
14\end{array}$ & $\begin{array}{l}14 \\
11\end{array}$ & 9 & 205 & 21 & $\begin{array}{r}9 \\
10\end{array}$ & 25 & $\begin{array}{r}2 \\
26\end{array}$ & 4 & 10 & 10 & 12 & 220 & 255 \\
\hline 13 & 3 & 421 & 10 & 700 & 689 & 11 & 47 & & 3 & 6 & 4 & $(7,2)$ & & \\
\hline 14 & 470 & 390 & 11 & 81 & 1 & 12 & 180 & 17 & 6 & 145 & 1285 & 7 & 379 & 319 \\
\hline & & & $\begin{array}{l}12 \\
13\end{array}$ & 154 & 17. & 13 & 256 & 228 & 7 & 901 & 787 & 8 & 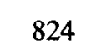 & 843 \\
\hline$(3,0)$ & & & 13 & 333 & 35 & & & & 8 & 1439 & 1371 & 9 & & $\begin{array}{r}845 \\
44\end{array}$ \\
\hline 3 & 733 & 568 & 18 & & & $(4,1)$ & & & 9 & 163 & 54 & & & 274 \\
\hline 4 & 1 & 161 & $(8,0)$ & & & 4 & 58 & 49 & 10 & 2 & 274 & 11 & 480 & 50 \\
\hline 5 & 920 & 846 & 8 & 1961 & 211 & 5 & 6 & 5 & 11 & 37 & 41 & 12 & 527 & 59 \\
\hline 6 & 594 & 540 & 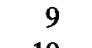 & 10 & 17 & 6 & 22 & 19 & 12 & 990 & 1057 & 13 & 172 & 20 \\
\hline 7 & 468 & 456 & 10 & 17 & 16 & 7 & 98 & 105 & 13 & 435 & 575 & $3,2)$ & & \\
\hline 8 & 88 & 8 & $\begin{array}{l}11 \\
12\end{array}$ & $\begin{array}{l}261 \\
792\end{array}$ & 260 & 8 & 118 & 51 & & & & 8 & & 21 \\
\hline 10 & $\begin{array}{l}388 \\
576\end{array}$ & $\begin{array}{l}421 \\
633\end{array}$ & 12 & 792 & 858 & 10 & 467 & 459 & $(3,2)$ & & & 8 & 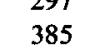 & 21 \\
\hline 11 & $\begin{array}{r}36 \\
81\end{array}$ & $\begin{array}{l}633 \\
102\end{array}$ & $(9,0)$ & & & $\begin{array}{l}10 \\
11\end{array}$ & $\begin{array}{l}518 \\
146\end{array}$ & $\begin{array}{r}516 \\
70\end{array}$ & $\begin{array}{l}3 \\
4\end{array}$ & $\begin{array}{l}205 \\
214\end{array}$ & $\begin{array}{l}22 \\
17\end{array}$ & 10 & 103 & 10 \\
\hline 12 & 210 & 205 & 9 & 457 & 464 & 12 & 80 & 30 & 5 & 583 & 549 & 11 & 84 & 10 \\
\hline 13 & 307 & 311 & 10 & 311 & 284 & 13 & 341 & 351 & 6 & 252 & 257 & 12 & 489 & 522 \\
\hline
\end{tabular}


TABLE I-continued

\begin{tabular}{|c|c|c|c|c|c|c|c|c|c|c|c|c|c|c|}
\hline$h$ & $F_{\text {obsd }}$ & $F_{\text {cald }}$ & $h$ & $F_{\text {obsd }}$ & $F_{\text {cald }}$ & $h$ & $F_{\text {obsed }}$ & $F_{\text {cald }}$ & $h$ & $F_{\text {obed }}$ & $F_{\text {cald }}$ & $h$ & $F_{\text {obsd }}$ & $F_{\text {cald }}$ \\
\hline \multicolumn{3}{|l|}{$(9,2)$} & \multicolumn{3}{|c|}{$(5,3)-($ continued $)$} & \multicolumn{3}{|c|}{$(4,4)-($ continued $)$} & \multicolumn{3}{|l|}{$(9,4)$} & \multicolumn{3}{|c|}{$(6,6)-($ continued $)$} \\
\hline \multirow[t]{2}{*}{9} & 114 & 137 & 12 & 266 & 238 & 8 & 1167 & 1028 & 9 & 432 & 438 & 10 & 364 & 363 \\
\hline & & & 13 & 225 & 158 & 9 & 569 & 565 & 10 & 543 & 529 & 11 & 491 & 550 \\
\hline$(3,3)$ & & & $(6,3)$ & & & 10 & 1203 & 1284 & $(5,5)$ & & & \multirow{2}{*}{\multicolumn{3}{|c|}{$(7,6)$}} \\
\hline 3 & 1312 & 1343 & 6 & 673 & 610 & 11 & 149 & 200 & 5 & 507 & 400 & & & \\
\hline 4 & 188 & 150 & 7 & 480 & 434 & 12 & \multirow[t]{2}{*}{312} & \multirow[t]{2}{*}{376} & 6 & 394 & 341 & 7 & 856 & 723 \\
\hline 5 & 1447 & 1424 & 8 & 121 & 28 & $(5,4)$ & & & 7 & 954 & 859 & 8 & 276 & 263 \\
\hline 6 & 415 & 387 & 9 & 125 & 179 & 5 & 460 & 421 & 8 & 846 & 816 & 9 & 120 & 35 \\
\hline 7 & 836 & 784 & 10 & 394 & 439 & 6 & 211 & 146 & 9 & 1171 & 1117 & 10 & 371 & 351 \\
\hline 8 & 295 & 285 & 11 & 197 & 177 & 7 & 373 & 330 & 10 & 96 & 142 & 11 & 263 & 276 \\
\hline 9 & 311 & 270 & 12 & 84 & 152 & 8 & 441 & 366 & 11 & 510 & 481 & & & \\
\hline 10 & 404 & 400 & 13 & 188 & 205 & 9 & 563 & 506 & 12 & 332 & 370 & $(8,6)$ & & \\
\hline 11 & 1310 & 1456 & & & & 10 & 394 & 365 & (6. 5 & & & 8 & 257 & 254 \\
\hline 12 & 327 & 350 & $(7,3)$ & & & 11 & 211 & 271 & $(0,3)$ & & & 9 & 120 & 9 \\
\hline 13 & 169 & 106 & 7 & 954 & 861 & 12 & 152 & 147 & 6 & 117 & 102 & 10 & 354 & 354 \\
\hline & & & 8 & 331 & 332 & 13 & 401 & 404 & 7 & 120 & 101 & & & \\
\hline$(4,3)$ & & & 9 & 438 & 427 & & & & 8 & 478 & 442 & $(7,7)$ & & \\
\hline 4 & 647 & 581 & 10 & 455 & 452 & $(6,4)$ & & & 9 & 126 & 182 & 7 & 1038 & 931 \\
\hline 5 & 721 & 670 & 11 & 1026 & 1075 & 6 & 388 & 300 & 10 & 309 & 320 & 8 & 124 & 102 \\
\hline 6 & 348 & 318 & 12 & 124 & 97 & 7 & 448 & 406 & 11 & 410 & 485 & 9 & 320 & 353 \\
\hline 7 & 115 & 7 & $(8,3)$ & & & 8 & 368 & 313 & 12 & 470 & 472 & 10 & 599 & 582 \\
\hline 8 & 483 & 441 & 8 & 108 & 95 & 9 & 230 & 186 & $(8,5)$ & & & 11 & 1034 & 1090 \\
\hline 9 & 383 & 360 & 9 & 163 & 60 & 10 & 102 & 60 & 8 & 9 & 80 & & & \\
\hline 10 & 91 & 22 & 10 & 440 & 507 & 11 & 91 & 64 & 9 & 471 & 442 & ) & & \\
\hline 11 & 197 & 199 & 11 & 227 & 335 & $(7,4$ & & & 10 & 406 & 426 & 8 & 418 & 406 \\
\hline 12 & 88 & 94 & 12 & 307 & 372 & $(1,4$ & & & 10 & 301 & $\begin{array}{l}420 \\
305\end{array}$ & 10 & 105 & 116 \\
\hline 13 & 74 & 133 & & & & 7 & 309 & 274 & & & $30 s$ & & & \\
\hline & & & $(9,3$ & & & 8 & 342 & 288 & $(9,5)$ & & & $(9,7)$ & & \\
\hline$(5,3)$ & & & 9 & 113 & 228 & 9 & 176 & 97 & 9 & 614 & 684 & 9 & 285 & 344 \\
\hline 5 & 1011 & 926 & 10 & 175 & 221 & 10 & 200 & 148 & 10 & 122 & 201 & $(8,8)$ & & \\
\hline 6 & 108 & $\begin{array}{r}920 \\
62\end{array}$ & 11 & 227 & 250 & 11 & 88 & 5 & 11 & 190 & 200 & $(0,0)$ & & \\
\hline 7 & 825 & 690 & $(4,4)$ & & & $(8,4)$ & & & $(6,6)$ & & & 8 & 474 & 482 \\
\hline 8 & 416 & 393 & 4 & 671 & 560 & 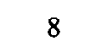 & 4. & 409 & 6 & 88 & & 9 & 355 & 341 \\
\hline 9 & 668 & 667 & 5 & 931 & 814 & 9 & 257 & 251 & 0 & & & 10 & 846 & 853 \\
\hline 10 & 655 & 726 & 6 & 824 & 698 & 10 & 36 & 30 & 7 & 606 & 591 & 7 & & \\
\hline 11 & 266 & 240 & 7 & 521 & 473 & 11 & 243 & 206 & 0 & $\begin{array}{l}120 \\
283\end{array}$ & $\begin{array}{r}46 \\
236\end{array}$ & 0 & & \\
\hline & & & & & & & & & & & & & & \\
\hline
\end{tabular}

a The indices for $(k, l)$ are given in parentheses above each grouping.

\section{Structure Determination}

Using an isotropic cleavage fragment of dimensions $0.08 \times 0.14 \times 0.40 \mathrm{~mm}$ and equiinclination Weissenberg geometry, a total of 1560 intensities were measured on an automated singlecrystal diffractometer. Graphite flat-crystal mono-chromated $\mathrm{Cu} K \alpha$ radiation and pulse height analysis were employed. The data were corrected for Lorentz, polarization, and absorption effects. Symmetrically equivalent reflections were then averaged to obtain the final set of $360|F|_{\text {obsd }}$ values.
The data were then used to calculate the Patterson function of boleite. Interatomic vectors were also calculated from the atomic positions in Ito's untwinned cubic structure. Comparison of the two vector sets showed that two of the five cation sites in Ito's structure were occupied by heavy atoms. Starting with these two atoms, the rest were located by means of successive electron density syntheses.

Refinement of the structure was carried out by the method of least-squares using the IBM 360 program SFLSQ5 written by C. T. Prewitt. 
TABLE II

Positional And Thermal Parameters in Boleite ${ }^{a}$

\begin{tabular}{lcccc}
\hline Atom & $x$ & $y$ & $z$ & $B\left(\AA^{2}\right)$ \\
\hline $\mathrm{Pb}(1)$ & $0.2269(5)$ & $\frac{1}{2}$ & $\frac{1}{2}$ & $1.4(2)$ \\
$\mathrm{Pb}(2)$ & $0.3030(2)$ & 0.3030 & 0.3030 & $1.0(1)$ \\
$\mathrm{Pb}(3)$ & $0.2734(3)$ & $\frac{1}{2}$ & 0 & $1.4(1)$ \\
$\mathrm{Ag}(1)$ & 0 & $0.1561(10)$ & 0 & $2.2(3)$ \\
$\mathrm{Ag}(2)$ & 0 & $\frac{1}{2}$ & 0 & $3.2(5)$ \\
$\mathrm{Cu}$ & $0.2563(5)$ & 0.2563 & $0.0925(7)$ & $0.7(2)$ \\
$\mathrm{Cl}(1)$ & $0.1233(16)$ & 0.1233 & 0.1233 & $2.4(8)$ \\
$\mathrm{Cl}(2)$ & $0.3864(10)$ & 0.3864 & $0.1218(15)$ & $2.0(4)$ \\
$\mathrm{Cl}(3)$ & 0 & $0.3354(32)$ & 0 & $2.0(9)$ \\
$\mathrm{Cl}(4)$ & $0.1311(14)$ & $\frac{1}{2}$ & 0.1311 & $1.9(7)$ \\
$\mathrm{Cl}(5)$ & $0.3282(14)$ & $\frac{1}{2}$ & 0.3282 & $1.9(6)$ \\
$\mathrm{OH}(1)$ & 0 & $0.3218(30)$ & $0.2060(30)$ & $0.2(10)$ \\
$\mathrm{OH}(2)$ & $0.1831(28)$ & 0.1831 & $0.3300(43)$ & $3.3(14)$ \\
& & & & \\
\hline
\end{tabular}

a Standard errors to the least significant digit are shown in parentheses.

Scattering factors for $\mathrm{Pb}^{+}$and $\mathrm{Ag}^{+1 / 2}$ were obtained from Cromer and Waber (8), $\mathrm{Cu}^{+}$and $\mathrm{Cl}^{-1 / 2}$ from Doyle and Turner (9), and $\mathrm{O}^{-}$from the "International Tables for X-ray Crystallography" (10). Anomalous dispersion corrections for $\mathrm{Pb}, \mathrm{Ag}, \mathrm{Cu}$, and $\mathrm{Cl}$ were taken from Cromer (11). Refinement was carried out using isotropic atomic temperature factors. All reflections, excluding $F_{\text {obsd }}<F_{\min }$, were equally weighted. The final $R$ value is $10.5 \%$ for all reflections or $8.9 \%$ if the unobserved reflections are excluded. Table I contains a list of structure factors and Table II, the refined atomic parameters. Interatomic distances and their standard errors (Table III) were calculated with the program ORFFE of Busing, Martin, and Levy (12) using the variance-covariance matrix for atomic coordinates.

\section{Structure and Bonding}

Although the unit cell of boleite corresponds to that found by Ito, his proposed crystal structure is quite different from the one described here. Before giving a detailed description of this complex structure, it is desirable to provide a brief overview.

The structure of boleite is based upon a distorted body-centered framework of lead and silver atoms. Only the three $\mathrm{Ag}(2)$ atoms are not part of the body-centercd array. Since an octahedron may be inscribed within a pair of body-
TABLE III

INTERATOMIC DISTANCES ${ }^{a}$ (IN $\AA$ )

$\begin{array}{cccc}\mathrm{Pb}(1)-4 \mathrm{Cl}(2) & 2.94(2) & \mathrm{Cl}(1)-3 \mathrm{OH}(2) & 3.41(8) \\ 4 \mathrm{Cl}(5) & 3.05(1) & 3 \mathrm{Cl}(1) & 3.77(5) \\ \mathrm{Pb}(2)-3 \mathrm{OH}(2) & 2.63(6) & 6 \mathrm{OH}(1) & 3.79(4) \\ 3 \mathrm{Cl}(5) & 3.06(1) & \mathrm{Cl}(2)-2 \mathrm{OH}(2) & 3.36(4) \\ 3 \mathrm{Cl}(2) & 3.31(2) & 2 \mathrm{OH}(1) & 3.47(4) \\ \mathrm{Pb}(3)-2 \mathrm{OH}(1) & 2.91(5) & 2 \mathrm{Cl}(2) & 3.47(3) \\ 2 \mathrm{Cl}(4) & 2.96(1) & 2 \mathrm{Cl}(5) & 3.71(2) \\ 4 \mathrm{Cl}(2) & 3.08(1) & \mathrm{Cl}(2) & 3.72(5) \\ 2 \mathrm{~Pb}(3) & 4.900(7) & \mathrm{Cl}(3)-4 \mathrm{OH}(1) & 3.16(5) \\ 2 \mathrm{~Pb}(1) & 4.903(6) & 4 \mathrm{Cl}(4) & 3.79(4) \\ \mathrm{Ag}(1)-4 \mathrm{Cl}(1) & 2.71(3) & 4 \mathrm{OH}(2) & 3.96(6) \\ \mathrm{Cl}(3) & 2.74(5) & \mathrm{Cl}(4)-2 \mathrm{OH}(2) & 2.83(6) \\ 4 \mathrm{Ag}(1) & 3.38(2) & 4 \mathrm{OH}(1) & 3.57(4) \\ \mathrm{Ag}(2)-2 \mathrm{Cl}(3) & 2.52(5) & 2 \mathrm{Cl}(4) & 4.01(4) \\ 4 \mathrm{Cl}(4) & 2.83(3) & \mathrm{Cl}(5)-4 \mathrm{Cl}(5) & 3.71(3) \\ \mathrm{Cu}-2 \mathrm{OH}(1) & 1.90(3) & \mathrm{OH}(1)-\mathrm{OH}(1) & 2.50(9) \\ 2 \mathrm{OH}(2) & 2.11(4) & 2 \mathrm{OH}(2) & 2.82(4) \\ \mathrm{Cl}(2) & 2.85(2) & \mathrm{OH}(2)-2 \mathrm{OH}(2) & 3.18(11) \\ \mathrm{Cl}(1) & 2.91(3) & & \\ \mathrm{Cu} & 2.83(2) & & \\ \mathrm{Pb}(2) & 3.37(1) & & \\ 2 \mathrm{Cu} & 3.54(2) & & \\ & & & \end{array}$

${ }^{a}$ Standard errors in parentheses.

centered cubic cells, this arrangement leads to octahedral groupings of lead and silver atoms in boleite. Coordinated to the faces and vertices of the metal polyhedra are chlorine atoms. These chlorines are shared with $\mathrm{Ag}(2) \mathrm{Cl}_{6}$ and $\mathrm{Cu}(\mathrm{OH})_{4} \mathrm{Cl}_{2}$ distorted octahedra such that the anion polyhedra form bridges between the metal polyhedra. Individual lead atoms are coordinated by distorted square antiprisms of chlorine and hydroxyl ions. These antiprisms are linked in a complex fashion by shared faces and vertices. The octahedra around the copper atoms are likewise linked by shared edges.

Looking at the structure in detail, the $\mathrm{Ag}(1)$ atoms form a regular octahedron centered at the unit-cell origin. Eight $\mathrm{Cl}(1)$ atoms are located above the faces of the octahedron and six $\mathrm{Cl}(3)$ atoms lie adjacent to the six octahedral vertices (Fig. 1). This is the same configuration found in the well-known metal cluster compounds $\mathrm{NbI}_{1.83}, \mathrm{MoCl}_{2}, \mathrm{WCl}_{2}$, and their derivatives (13). By analogy, boleite is a metal cluster compound, the first reported involving silver and a halogen. Silver(I) dipropyldithiocarbamate contains a distorted $\mathrm{Ag}_{6}$ octahedron (14), but the silveranion arrangement is unrelated to that in boleite. 


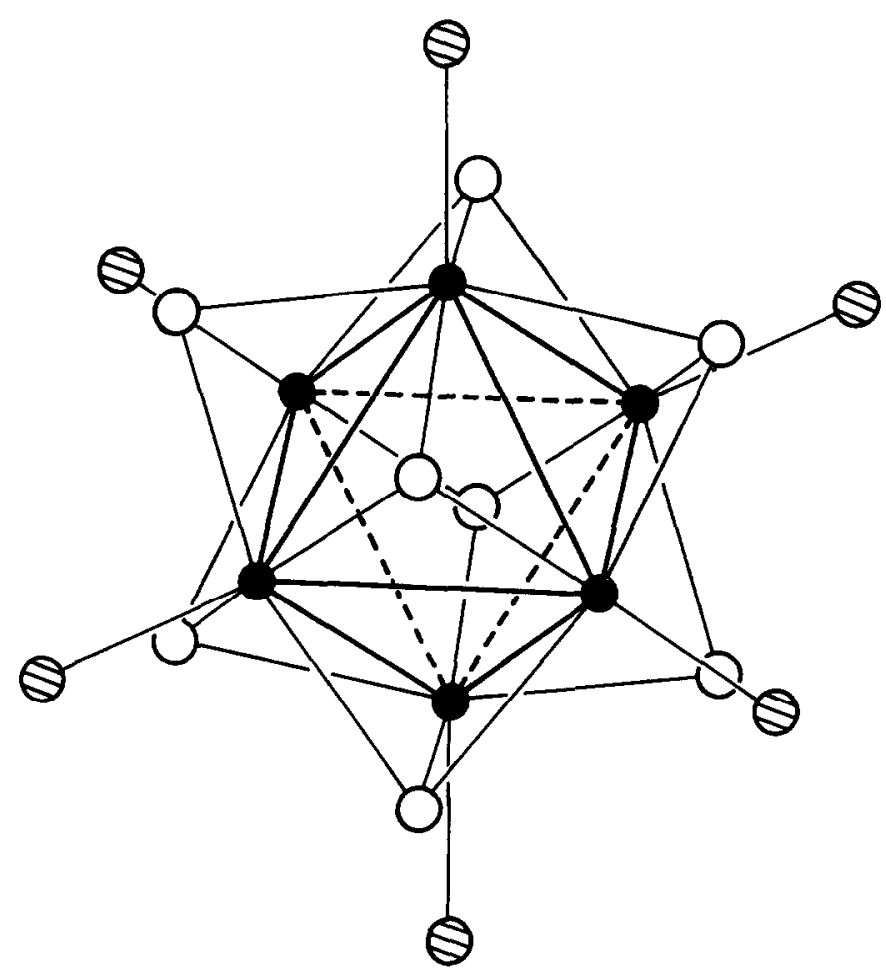

FIG. 1. The $\mathrm{Ag}_{6} \mathrm{Cl}_{8} \mathrm{Cl}_{6}$ group in boleite.

Within the $\mathrm{Ag}_{6}$ octahedron of boleite the $\mathrm{Ag}-\mathrm{Ag}$ distance is $3.38 \AA$. This is longer than in silver metal $(2.89 \AA)$ and no claim is made here for the existence of metal-metal bonds in boleite. The $\operatorname{Ag}(1)$ octahedron, which is centered at 000 , shares $\mathrm{Cl}(3)$ atoms with three $\mathrm{Ag}(2) \mathrm{Cl}_{6}$ tetragonal bipyramids. The latter are centered at $\frac{1}{2} 00$ and equivalent positions. Along the unit cell edges the sequence of polyhedra is therefore $\mathrm{Ag}_{6}$ octahedron- $\mathrm{AgCl}_{6}$ bipyramid- $\mathrm{Ag}_{6}$ octahedron. $\mathrm{Ag}(1)$ is coordinated by four chlorine atoms at $2.71 \AA$ and one morc at $2.74 \AA$. These $\mathrm{Ag}-\mathrm{Cl}$ distances are comparable to that in $\mathrm{AgCl}(2.77 \AA)$ and to the sum of the covalent radii, $2.78 \AA$ (15). $\mathrm{Ag}(2)$ is coordinated by two chlorine atoms at $2.52 \AA$ and another four at $2.83 \AA$. Analogously, in $\mathrm{Cs}_{2} \mathrm{AgAuCl}_{6}$ (16), there are distorted $\mathrm{AgCl}_{6}$ octahedra which have two $\mathrm{Ag}-\mathrm{Cl}$ distances of $2.36 \AA$ and four more of $2.92 \AA$. The two short bonds result from the tendency of $\mathrm{Ag}^{\mathrm{I}}$ to form pairs of linear covalent bonds.

Also of interest are the nearly regular $\mathrm{Pb}_{6}$ octahedra centered at $\frac{11}{2} 0$ and equivalent positions. Here the $\mathrm{Pb}-\mathrm{Pb}$ distances are 4.900 and $4.903 \AA$, which are much greater than in lead metal $(3.50 \AA)$. Above each octahedron face is a $\mathrm{Cl}(2)$ atom, but there are no anions adjacent to the vertex metal atoms as in the silver octa hedron.

$\mathrm{Pb}(1), \mathrm{Pb}(2)$, and $\mathrm{Pb}(3)$ are coordinated by distorted square antiprisms of chlorine and/or hydroxyl ions much as in diaboleite, $\mathrm{Pb}_{2} \mathrm{Cu}(\mathrm{OH})_{4} \mathrm{Cl}_{2}$ (17). The antiprism around $\mathrm{Pb}(2)$ is grossly distorted and includes a ninth ligand. $\mathrm{Pb}-\mathrm{OH}$ distances in these polyhedra are 2.63 and $2.91 \AA$, and $\mathrm{Pb}-\mathrm{Cl}$ distances range from 2.94 to $3.31 \AA$. These are typical of distances in ionic lead oxychlorides (17). The $\mathrm{Pb}(1)$ and $\mathrm{Pb}(2)$ antiprisms share faces to form an eight-membered ring, and the $\mathrm{Pb}(3)$ antiprisms share edges to form a separate four-membered ring. Both rings are centered around the axis $\frac{1}{2} \frac{1}{2} z$ and are joined by shared vertices.

Copper atoms are coordinated by two $\mathrm{OH}$ groups at $1.90 \AA$, another two at $2.11 \AA$, and two chlorine atoms at 2.85 and $2.91 \AA$. Together they form a distorted tetragonal bipyramid around the $\mathrm{Cu}^{+2}$ ion. Each $\mathrm{Cu}(\mathrm{OH})_{4} \mathrm{Cl}_{2}$ bipyramid shares edges and a common vertex (A in Fig. 2) with two others to form a trimer around the [111] axis. Next, each trimer shares edges (BC and DE) with two other trimers. These two then share edges with a fourth to form a four-membered ring of trimers around the axis 


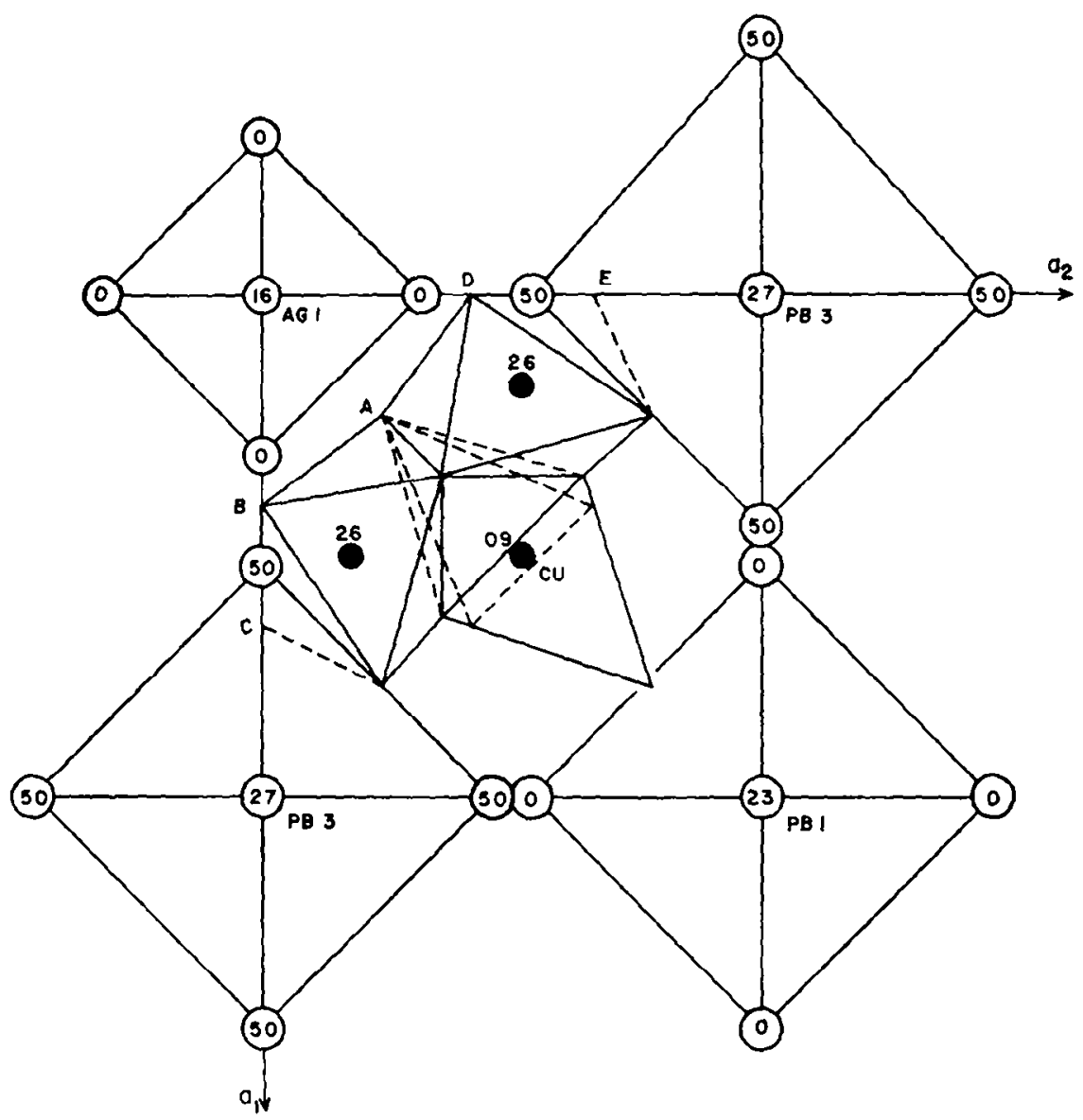

Fig. 2. Projection on (001) of $\frac{1}{8}$ of the unit cell. Some atoms are omitted for clarity. The $\mathrm{Ag}_{6}$ and $\mathrm{Pb}_{6}$ octahedra are shown along with a trimer of Cu coordination polyhedra. Numerals are heights of atoms in $z \times 100$.

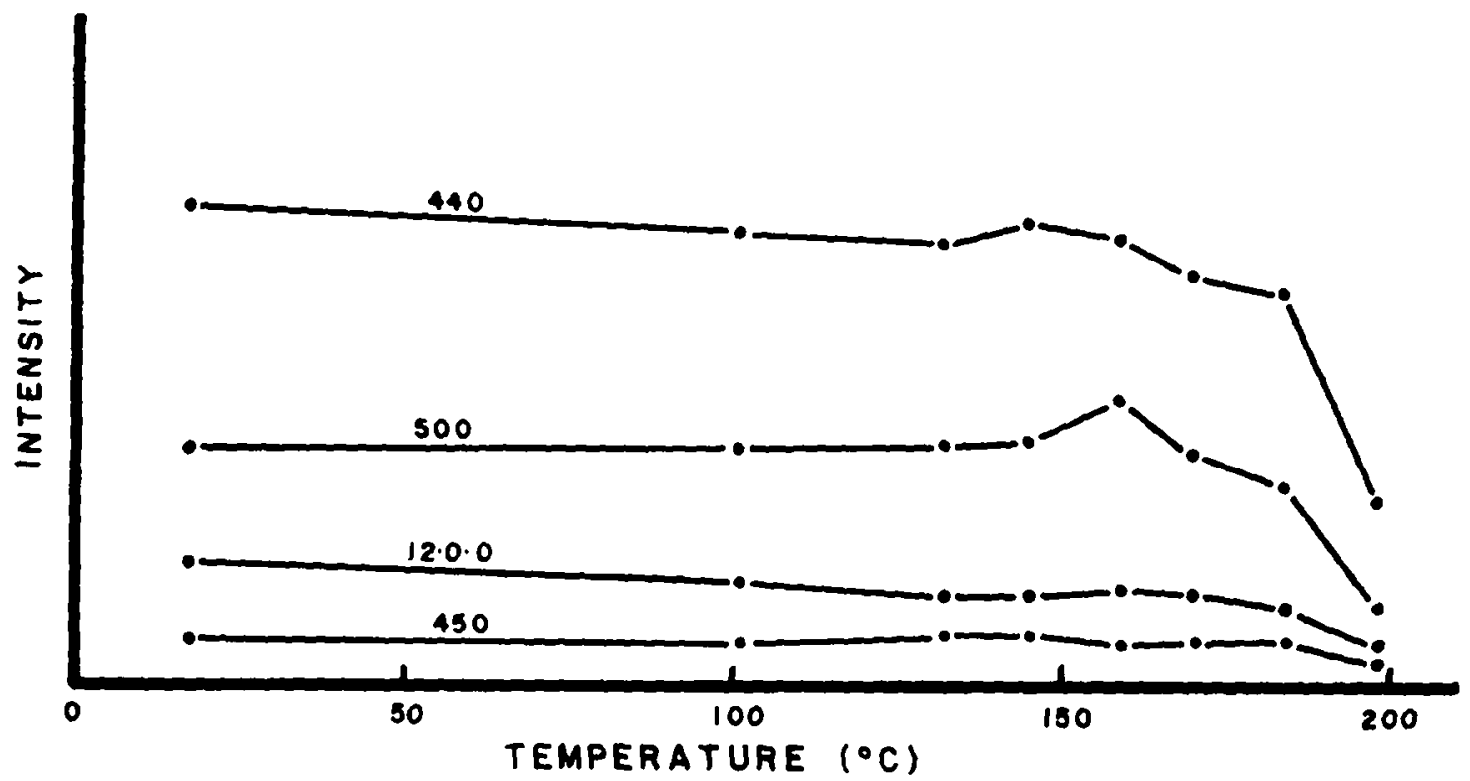

FIG. 3. Plot of integrated intensity vs temperature for several reflections. 
$00 z$. Since the basal plane of the unit cell is a mirror plane, the ring is duplicated by reflection in the next unit-cell down. Thus, there are two rings, each composed of four trimers. These two rings are also joined by shared edges. $\mathrm{Cu}-\mathrm{Cu}$ distances across these shared edges are very short $(2.83 \AA)$ compared to those within an individual trimer (3.54 $\AA$ ). The very short $\mathrm{OH}(1)-\mathrm{OH}(1)$ separation of $2.50 \AA$ is the edge shared between trimers. To the author's knowledge, this configuration of copper coordination polyhedra is unique.

\section{High Temperature Study}

In order to check the conclusions of (7) with respect to polymorphism in boleite, a cleavage fragment was mounted in a high temperature furnace attached to a single-crystal diffractometer. The intensities of four reflections were monitored (Fig. 3) as the crystal was slowly heated from 17 to $251^{\circ} \mathrm{C}$. The average heating rate was about $9^{\circ} \mathrm{C} / \mathrm{hr}$. No significant change occurred until $\sim 160^{\circ} \mathrm{C}$ when the intensities of all reflections began to decrease noticeably. When the crystal was examined by eye at $198^{\circ} \mathrm{C}$, its color had changed from blue to black. After heating to $251^{\circ} \mathrm{C}$ and cooling, an X-ray powder photograph of the crystal was obtained. It showed only lines due to $\mathrm{PbCl}_{2}, \mathrm{AgCl}$, and $\mathrm{CuO}$. In summary, no evidence was found for an inversion in boleite. The intensity change above $160^{\circ} \mathrm{C}$ is due to crystal decomposition, the black coating bcing $\mathrm{CuO}$. It should be noted that the heating rate in (7) was between $1^{\circ}$ and $4^{\circ} \mathrm{C} / \mathrm{min}$, hence equilibrium was probably not attained. The blue to green color change may have been due simply to small changes in bond lengths within the copper coordination polyhedron producing changes in the crystal field splittings. The attainment of complete isotropy probably resulted from the relief of strain in a cubic crystal.

\section{Acknowledgments}

The author wishes to thank Dr. Donald R. Peacor and Dr. Billy J. Evans for reading the manuscript and making helpful criticisms.

\section{References}

1. E. Mallard and E. Cumenge, Bull. Soc. Fr. Mineral. 14, 283 (1891).

2. G. Friedel, Bull. Soc. Fr. Mineral. 29, 14 (1906); Z. Kristallogr. 73, 147 (1930).

3. R. HoCART, $Z$. Kristallogr. 74, 20 (1930); Bull. Soc. Fr. Mineral. 57, 5 (1934).

4. A. Hadding, Geol. Foeren. Stockholm Foerh. 41, 175 (1919).

5. B. Gossner AND M. ARM. Z. Kristallogr. 72, 202 (1929); B. Gossner, $Z$. Kristallogr. 75, 365 (1930).

6. TeI-ICHI Ito, "X-ray Studies on Polymorphism," pp. 70-92. Maruzen, Tokyo (1950).

7. R. E. WINCHELL, Thesis, Ohio State University, 1963.

8. D. T. Cromer AND J. T. WABer, Acta Crystallogr. 18, 104 (1965).

9. P. A. Doyle And P. S. Turner, Acta Crystallogr. Sect. $A$ 24, 390 (1968).

10. "International Tables for X-ray Crystallography," Vol. III, p. 202. Kynoch Press, Birmingham, England (1962).

11. D. T. CRomer, Acta Crystallogr. 18, 17 (1965).

12. W. R. Busing, K. O. Martin, and H. A. Levy, Oak Ridge National Laboratory Report TM306. (1969).

13. M. C. BaIRD, Prog. Inorg. Chem. 9, 1 (1968).

14. R. Hesse ANd L. Nilson, Acta Chem. Scand. 23, 825 (1969).

15. J. A. Van Vechten and J. C. Phillips, Phys. Rev. B 2, 2160 (1970).

16. N. Elliot and L. Pauling, J. Amer. Chem. Soc. 60, 1846 (1938).

17. R. C. RousE, Z. Kristallogr. 134, 69 (1971). 